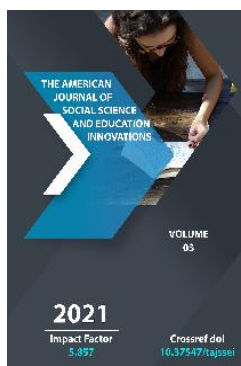

\title{
The Concept Of Aesthetic
}

\author{
Norali Berdiev \\ Candidate Of Philosophical Sciences, Associate Professor, Termez State University, Termez, \\ Uzbekistan
}

Journal Website:

http://theamericanjour

nals.com/index.php/taj

ssei

Copyright: Original content from this work may be used under the terms of the creative commons attributes 4.0 licence.

\section{ABSTRACT}

The article analyzes the mythological, religious, objectively idealistic, subjectively idealistic, dualistic, metaphysically materialistic, "naturalistic", "social", axiological concepts of the essence and characteristics of the aesthetic that existed in the history of philosophical and aesthetic thought. The achieved successes and the existing shortcomings of these concepts are summarized, the prospects for further study of the problem are outlined.

\section{KEYWORDS}

Aesthetic, mythology, religious concept, objectively idealistic concept, subjectively idealistic concept, dualistic concept, metaphysically materialistic concept, "naturalistic" concept, "social" concept, axiological concept.

\section{INTRODUCTION}

The topic "Aesthetic attitude of a person to reality" occupies an important, central place in the course of modern aesthetics. The aesthetic attitude of a person to reality is 
carried out through aesthetic phenomena, values. Therefore, it is advisable to begin the presentation of the topic with an analysis of the concepts of the aesthetic.

General theoretical and general methodological foundations of the problem of aesthetic are highlighted in classical aesthetics in the works of I.Kant, G.V.F.Hegel, N.G.Chernyshevsky, K.Marx, G.V.Plekhanov. Certain aspects of this problem have been studied in the scientific works of such scientists as V.F.Asmus, G.Z.Apresyan, A.I.Burov, Yu.B.Borev, V.V.Vanslov, A.I.Vinogradov, S.S. Goldentricht, N.A.Dmitrieva, A.Ya.Zis, V.P.Ivanov, M.S.Kagan, N.I.Kryukovsky, M.A.Lifshchits, A.F.Losev, G.A.Nedoshivin, M.F.Ovsyannikov, G.N.Pospelov, L.N.Stolovich, P.S.Trofimov and others.However, there are still few works devoted to a special, comprehensive study of this problem. In particular, special chapters on this topic are not included even in teaching aids on aesthetics of different years, separate articles in the "Philosophical Encyclopedia" (Moscow, 5-volume, 1970), "A Concise Dictionary of Aesthetics" (Moscow, 1964).

With this in mind, in this article we will try to give, at least briefly, an analysis of the concepts of the aesthetic.

\section{RESULTS AND DISCUSSION}

"Aesthetic" as a concept expressing the general, essential features of the beautiful, ugly, sublime, base, dramatic, tragic, comic, tragicomic, heroic, artistic and other phenomena, values, entered science relatively later, more precisely, in the 6os XX century. The phenomena listed above were considered as different sides, varieties of beauty. For this reason, the concept of beautiful has long been used in a broad sense instead of the concept of aesthetic, various concepts have been put forward about it.
The oldest teachings about the essence of the world, including the aesthetic phenomena in it, are mythology and religion. According to these teachings, the world and man were created by God. All phenomena in the world, including the beautiful, are a product, a manifestation of God, supernatural power. Of course, such an explanation of the issue is scientifically untenable. Later, with the emergence of philosophy in a slave society, objective idealism tried to explain this issue more or less scientifically.

An objectively idealistic concept (Socrates, Plato, Augustine, F.Aquinas, Hegel, neoThomism, etc.) recognizes the objective basis of the aesthetic, but explains it as a manifestation, a product of some idea, spirit or supernatural force that exist absolutely, eternally outside this world, space and time, human consciousness. Objective idealism, although it correctly notices the dialectics of the material and the spiritual in the aesthetic, nevertheless opposes them to each other. He considers the ideal to be primary in relation to the material, interprets it fantastically, religiously and idealistically. According to him, the true beauty is in the world of ideas, spirit, beauty in the world of things, the material world is deceptive, transient, temporary. From this point of view, the objectively idealistic concept is closely linked with religious teaching. It does not take into account the subjective moment in the aesthetic.

The subjective idealistic concept (D.Hume, I.Kant, I.Fichte, A. Schopenhauer, F.Nietzsche, positivism, intuitionism, Freudianism, existentialism, etc.) arose in the 18th-19th centuries. together with bourgeois social relations. Considering the place and significance of the subjective moment, aesthetic consciousness, aesthetic concepts, feelings and experiences, she has achieved significant results in their special study. But, 
denying the objective content, foundations and criteria of the aesthetic in general, she considered them as a product, a manifestation of consciousness, desire and will, feelings and experiences of the subject. Considering aesthetic phenomena as a purely individual and arbitrary assessment, devoid of objective content and criteria, the subjective idealistic concept preaches subjectivism and anarchy in aesthetics and art history.

Trying to comprehend and eliminate the onesidedness of objectively and subjectively idealistic concepts, a dualistic concept arose in the history of philosophical and aesthetic thought. Representatives of this concept (E.Meiman, B.Croce, N.Hartmann and others) correctly noted that in order to thoroughly explain the essence of the aesthetic, it is necessary to combine objective and subjective aspects in it. In fact, considering the objective and the subjective as completely independent, not interconnected with each other, parallel existing sides in the aesthetic, the dualists could not unite, but, on the contrary, tore them apart. As a result, instead of correcting the mistakes made by the objective and subjective idealistic concepts, the dualistic concept repeated them once again. Dualism is a kind of idealism. Within the framework of idealism, it is impossible to correctly explain the question of the relationship between the objective and subjective sides in the aesthetic.

In the struggle against idealistic concepts, starting from the slave-owning society, materialistic theories arose and developed in various forms.

The general merit of the supporters of materialistic theories in aesthetics (Heraclitus, Democritus, Aristotle, Lucretius Kar, L.B.Alberti, Leonardo da Vinci, A.Dürer, E.Burke, D.Diderot, G.E.Lessing, I.Herder, V.G.Belinsky, A.I.Herzen, N.G.Chernyshevsky, N.A.Dobrolyubov and others) is that they explained aesthetic phenomena in close relationship with objective properties, qualities, laws of the material world, and thus gave a crushing blow to religious and idealistic theories. However, it existed until the 40 s of the XIX century. pre-Marxian materialism (of course, the materialism of the Russian revolutionary democrats of the 19th century is an exception in this regard) had metaphysical limitations and shortcomings.

The metaphysical materialist concept that existed in pre-Marxian materialist aesthetics included the beautiful and other aesthetic phenomena in a number of natural properties of things and objects. Linking the objective foundations of the aesthetic with nature, she suffers from the shortcomings of naturalism. This concept did not understand the questions about the socio-historical essence of the aesthetic, actively transforming role of practice, the subjective factor in it. Therefore, she approached the aesthetic from a passivecontemplative, observant point of view.

Thus, the general limitation of idealistic and metaphysically materialistic concepts was that they could not correctly solve the issues of unity and contradiction between the objective and the subjective, the material and the ideal in the beautiful and other aesthetic phenomena. Of course, both idealists (for example, dualists) and materialists (for example, D.Diderot, I.Gerder) tried to solve this problem. However, the metaphysical method in their thinking did not contribute to the disclosure of the dialectical nature of aesthetic phenomena. Only in the middle of the 19th century. Russian revolutionary democrats, and most of all N.G.Chernyshevsky, came close to the materialistic and dialectical understanding of the essence of beauty. However, even N.G.Chernyshevsky could not completely free himself from the historically inevitable 
shortcomings inherent in pre-Marxian materialist aesthetics (for example, the flaws of anthropologism).

The limitations of the idealistic and metaphysical aesthetic concepts of past eras could be overcome, correctly, scientifically explain the essence of the aesthetic only on the basis of dialectical-materialistic doctrine. K. Marx and F. Engels laid the first cornerstones in this area, set out their valuable reflections on beauty and other aesthetic phenomena. However, the thoughts of the founders of Marxism about the aesthetic were not specially developed in the form of an integral, unified system, they were simultaneously stated in relation to the analysis of various scientific issues. The work of collecting and publishing, scientific research of these thoughts was carried out much later. In addition, in the study of aesthetic issues, scientists did not strictly observe the ontological, epistemological, sociological, psychological, axiological aspects of the philosophy of Marxism, the principles of materialist dialectics, as a result of which they made serious mistakes.

Despite this, research work in the field of the study of aesthetic issues did not stop. In this respect, scientific disputes on the aesthetic issues that took place in 1956 in the former USSR were of great importance. Especially in May 1961, a heated discussion began on the initiative of the teaching staff of the Department of Aesthetics of Moscow State University on the topic: "What is the nature and essence of beauty and aesthetics?" In addition to the scientists-aesthetics of the former USSR, scientists from such socialist countries of that time as Bulgaria, the German Democratic Republic, Czechoslovakia, Poland, and Hungary also took part in the discussion. Discussion materials were published on the pages of the magazines "Voprosy filosofii",
"Voprosy literatury", as well as other magazines and newspapers. On the basis of these materials, a collection of articles "Aesthetic" was published in Moscow in 1964. Thus, in the 6os of the twentieth century. the concept of aesthetic entered science, became the topic of scientific research

During the discussions of the $60 \mathrm{~s}$ of the twentieth century. a number of concepts of the aesthetic arose - "natural", "social" and axiological.

Common to the "natural" and "social" concepts is that they considered the aesthetic as an objective property of objects and phenomena of reality. However, when determining the degree of objectivity depending on natural or socio-historical factors, their points of view differed.

The "naturalistic" concept (N.A.Dmitrieva, G.N.Pospelov, I.F. Smolyaninov, N.I.Kryukovsky, P.S.Trofimov and others) included the aesthetic in a number of natural properties of things and objects. According to this concept, beauty is generated by nature, its essence is determined by the laws of the material world, therefore it exists before a person and society, even without them.

However, focusing on the existence of various natural-objective, technical and functional foundations, prerequisites for beauty (proportion, symmetry, volume, rhythm, pace, growth, optimality, etc.), "naturalists" have done a lot to study them. However, linking the objectivity of beauty only with nature, they were unable to explain its socio-historical essence, the role and significance of practice, the subjective factor in it. The "naturalists", although they considered themselves Marxists, actually repeated the mistakes made by pre-Marxian metaphysical materialism (naturalism, passive contemplation, observation). In addition, considering 
beautiful as a natural property, they made two more serious mistakes:

First, in their opinion, if the beautiful belongs to a number of natural properties of things and objects, then natural sciences should study it. Such a view of the question will lead to the transformation of aesthetics into one of the parts of natural science, leaving in doubt its existence as an independent philosophical science.

Secondly, all natural properties can be measured using various instruments. But the aesthetic, including the beautiful, cannot be measured; there are no instruments for measuring them. This idea was also emphasized by Plato in his time. If so, then the beautiful is not included in the range of natural properties of things and objects, they are studied not by natural science, but by aesthetics.

Criticism of the "naturalist" concept was made by representatives of the "social" concept.

According to the "social" concept (Yu.B.Borev, V.V.Vanslov, S.S. Goldentricht, M.S.Kagan, L.N.Stolovich, V.I.Tasalov, etc.), aesthetic, including among the beautiful, is not included in the number of natural properties, they are social properties, qualities. Beauty is not generated by nature, but by society, by man. Beauty in nature does not exist without man and society.

When explaining the essence of the aesthetic, the representatives of the "social" concept proceeded from the teachings of Karl Marx about the practical activity of man. According to this teaching, the essence of a person is determined by the fact that he is a social being, a phenomenon. Personality realizes a human relation to reality, nature. At the same time, reality and nature are drawn into the circle of social relations, "humanized". They exist as "inhuman" (wild, virgin, existing before and without man and society, not mastered by them) and "humanized" (in close relationship with man, society, mastered by them) nature. "Inhuman" nature, its objects and phenomena, their inherent properties, qualities, processes in themselves, ie. without a person, societies have no significance, value, are neither beautiful nor ugly. Only "humanized" nature, its objects and phenomena, being useful, significant in meeting the needs of man and society, are of a certain value. Things and objects of nature are "humanized" in the process of social and historical practice, labor, acquire human content, value. In the process of "humanization", two sides of a person's attitude to reality are manifested:

1. "Objectification" - the special generic essence of man as a social being is imprinted and reified in objects of nature.

2. "Disobjectification" - objects and things, expressing the essence of a person, will cease to exist as ordinary physical, material objects, acquire human value, meaningfulness.

Thus, according to the "social" concept, aesthetic and beautiful as special qualities, values arise in the process of involving objects and phenomena of reality in the circle of social relations, "humanization", they are introduced by man and society.

The "social" concept emphasizes the social essence of the aesthetic as a phenomenon that has a close relationship with a person, society and practice. She connects the question of the aesthetic with actively transforming human activity. At the same time, the representatives of this concept did not take into account the natural features of beauty, as a result of which they made a number of mistakes. 
The common mistake of the "naturalistic" and "social" concepts was that they considered the aesthetic as a purely objective property, did not take into account the significance of the subjective moment in it. In contrast to this, some researchers (for example, A.Nuikin) considered the aesthetic as a purely subjective psychological phenomenon, a factor in the consciousness of a person, a manifestation of her sensory activity. At its core, this so-called "psychological" point of view repeated the mistakes of subjective idealism.

Discussions of the $60 \mathrm{~s}$ of the twentieth century. suggested the need to develop some new concept capable of overcoming the existing one-sidedness, errors in the explanation of aesthetic issues. "The causes of controversy are based on cognitive contradictions, paradoxes, antinomies" [7: 443]. As a timely response to this vital need, an axiological concept arose (Greek axia value, significance, logos - word, doctrine, science - theory of values). It was developed by representatives of the "social" concept.

The axiological concept considers the aesthetic as a special universal, spiritual value, significance that arises in the process of interrelation between the subject and the object. According to her, the objective side of the aesthetic manifests itself as a value, and the subjective side as an aesthetic assessment. The axiological concept considers the aesthetic as a complex dialectical phenomenon, consisting of a close unity of objective and subjective, natural and social, material and spiritual, sensual and rational and other aspects. From this point of view, the axiological concept synthesized the successes achieved and was able to significantly overcome the mistakes of the previous concepts.

\section{CONCLUSION}

Thus, the mythological, religious, objectively idealistic, subjectively idealistic, dualistic, metaphysically materialistic, "naturalistic", "social", axiological concepts that existed in the history of philosophical and aesthetic thought were important in explaining the essence and characteristics of the aesthetic. The need for a comprehensive, comprehensive, in-depth study of aesthetic phenomena currently requires the development of a unified scientific theory of the aesthetic. This is possible through the creative assimilation of everything valuable, rational, found in the concepts of the past, as well as the synthesis of ontological, epistemological, axiological, sociological, psychological, communicative, semiotic and other approaches to the problem. As the history of philosophical and aesthetic thought testifies, this task can be successfully solved only on the basis of dialectical materialist philosophy.

\section{REFERENCES}

1. Гегель. Лекции по эстетике. //Соч., т. XIIXIV. - Москва: 1938-1958.

2. История эстетики. Памятники мировой эстетической мысли. В 5-ти т. - Москва: 1962-1970.

3. Кант И. Критика способности суждения. //Соч., т. V. - Москва: 1966.

4. Природа и функции эстетического. Москва: 1968.

5. Столович Л.Н. Природа эстетической ценности. - Москва: 1972.

6. Столович Л.Н. Эстетическая и художественная ценность: сущность, специфика, соотношение. - Москва: 1983.

7. Turabova S. The importance of the discussion method in the development of argumentative competence in students // The American Journal of Social Science 
The American Journal of Social Science and Education Innovations (ISSN - 2689-100x)

Published: May 31, 2021 | Pages: 397-402

Doi : https://doi.org/10.37547/tajssei/Volume03Issue05-71

2021: 5.857

OCLC - 1121105668

and Education Innovations Published:

September 29, 2020 | Pages: 443-444

8. Эстетика. Словарь. Под общ. ред.

А.А.Беляева и др. - Москва: 1989.

9. Эстетическое. Сб. статей. - Москва: 1964. 